\title{
HILGARDIA
}

A Journal of Agricultural Science Published by the California Agricultural Experiment Station

CONTENTS

SYMPTOMATIC AND ETIOLOGIC RELATIONS OF THE CANKER AND THE BLOSSOM BLAST OF PYRUS AND THE BACTERIAL CANKER OF PRUNUS

EDWARD E. WILSON

INHERITANCE OF RESISTANCE TO POWDERY MILDEW IN BEANS

BJARNE DUNDAS

SPOTTED WILT OF THE SWEET PEA

W. C. SNYDER AND H. REX THOMAS 


\section{SPOTTED WILT OF THE SWEET PEA}

W. C. SNYDER AND H. REX THOMAS 



\title{
SPOTTED WILT OF THE SWEET PEA ${ }^{1}$
}

\author{
W. C. SNYDER ${ }^{2}$ AND H. REX THOMAS ${ }^{3}$
}

\section{INTRODUCTION}

IN THE COASTAL COUNTIES of California the sweet pea, Lathyrus odoratus L., is frequently afflicted with a streak disease. The cause of the disease is sometimes obscured by viruses of the mosaic type or by resemblance to the description of bacterial streak of sweet pea. ${ }^{(5)}{ }^{4}$ It has, however, been proved to be a virus identical with that responsible for the spotted wilt disease of tomato. Recently ${ }^{(6)}$ this virus has been reported as the cause of a streak disease of the garden pea, Pisum sativum L.

\section{SYMPTOMS}

A characteristic symptom of the disease on sweet pea is a necrotic streaking of stems and petioles. The streaks are reddish brown to dull purple in color and in the advanced stage are conspicuous. They may run the entire length of the stem, parallel to the long axis, being found on analysis to consist of disconnected short streaks or a continuous long one. They have been seen to develop both above and below the point of virus inception.

Leaves and shoots may turn yellow and die. Early symptoms on the foliage appear as spots, usually 5 to $15 \mathrm{~mm}$ long, more or less circular or oval in shape, yellowish at first, with diffuse margins. Later the spots become somewhat brownish and form a pattern typical of the virus on other hosts. From these spots are developed yellowish sectors or zones, ordinarily one or only a few on each leaf. The spotting of the foliage is fairly definite in early stages, although not striking; but the general yellowing which may follow becomes a conspicuous symptom. Symptoms of the disease are shown in figure $1, A$ and $D$.

Blossoms on infected plants have been seen to develop a circular pattern in the pigment and the virus has been recovered from such material. Again, blighting of the whole shoot may occur prior to blossom formation.

Variability in the expression of symptoms has been observed. Plants infected early may yellow and die without showing other symptoms. In other cases the virus may be limited to local lesions instead of becoming

1 Received for publication August 19, 1936.

2 Junior Plant Pathologist.

${ }^{3}$ Graduate Assistant in Plant Pathology.

${ }^{4}$ Superseript numbers in parentheses refer to Literature Cited at end of this paper. 


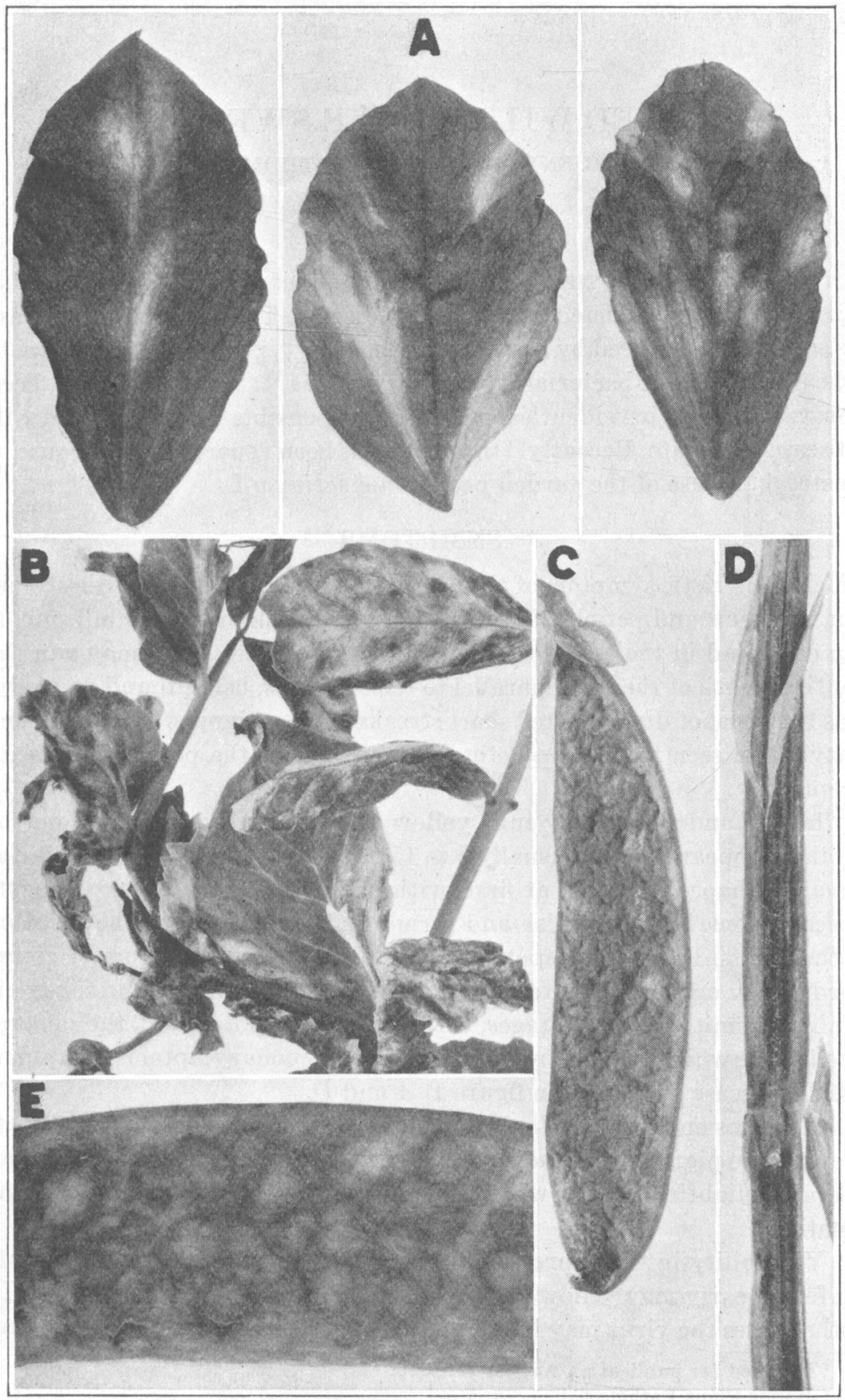

Fig. 1.-Symptoms of the spotted-wilt virus: $A$, Yellowish foliage spots on sweet pea. $B$, Brown foliage spots and blighting on garden pea. $C$, Pitted necrosis of pod of garden pea. Ovules failed to develop in this pod. $D$, Dark reddishbrown streak on stem of sweet pea. $E$, Circular pattern on pod of garden pea $(\times 2)$. 
systemic. This is frequently the case in artificial inoculations wherein lesions remain confined to the zone immediately above and below the inoculated leaves. Such infection does not result in the severe stunting and destructiveness obtained with systemic infections unless, as sometimes happens, the stem is so weakened that it breaks at the point of inoculation.

\section{INOCULATION EXPERIMENTS}

The diseased sweet-pea plants first used successfully as inoculum in the artificial transmission of the virus and in its determination were obtained in November. They were taken from a severe infestation of streak in a greenhouse devoted to sweet-pea culture at San Pablo, where spotted wilt is prevalent. The plants, only a few inches aboveground when infected, showed stem streaking, spotting of the foliage, general yellowing, and blighting of the shoots. They were free from mosaics. In some cases symptoms were confined to the blighted shoot, since subsequent shoots developed on the same root seemed to be normal for the time being. In other instances the virus became systemic, and where such plants survived to produce bloom, they sometimes bore flowers showing pigment patterns in the petals, as described above.

Expressed juice from the naturally infected sweet peas was inoculated by means of the carborundum rubbing method ${ }^{(3)}$ into healthy sweet peas and test plants for the spotted wilt virus. In four trials with fresh collections of the diseased sweet peas, the virus was successfully transmitted into Nicotiana glutinosa L., N. tabacum L., Datura stramonium L., and Lycopersicum esculentum Mill. Local lesions obtained on $N$. glutinosa and N. tabacum, as well as systemic infections induced in these and in D. stramonium and L. esculentum were all typical for the spotted wilt virus.

The sweet-pea plants which became infected resembled the original material, and the virus was recovered from them in turn on the test plants. Although transmission of the virus from sweet pea to the other hosts used in these trials was obtained fairly readily, the percentage of sweet-pea plants which became infected was low, varying from 0 to 60 per cent. This is in line with experience in other instances where the spotted wilt virus has been concerned. The incubation period varied usually from 14 to 30 days.

These results indicate that the spotted wilt virus of tomato was present in the diseased sweet peas, and that it could be recovered on other host plants by the mechanical method of transmission used.

By reversing the procedure of inoculation, healthy sweet peas (Red Boy variety) were inoculated from a tomato plant containing the spotted 
wilt virus. Streak symptoms appeared on 4 plants out of 13 inoculated. Inoculations with the virus from other host plants of the spotted wilt virus gave similar results in repeated tests, although in still other cases negative results were obtained. A trial with naturally infected Romaine lettuce, Lactuca sativa L. var. longifolia Lam., grown near the greenhouse where the disease was found on sweet pea, produced 8 infections out of a total of 30 inoculated sweet-pea plants. This appeared to identify further the spotted wilt virus in the field with that in the greenhouse. The lower transoms of the greenhouse had been left open after planting to sweet peas, ample opportunity thus being offered for thrips, the known vector of the spotted wilt virus, to enter in large numbers. Also, at that season the disease was spreading rapidly in nearby fields of head lettuce, L. sativa var. capitata L.

The results of these experiments show that by mechanical inoculations and cross-inoculations it is possible to produce symptoms typical of spotted wilt of tomato and streak of sweet pea, irrespective of the virus source. Sweet peas naturally infected with streak were used on the one hand, and plants inoculated by known cultures of the spotted wilt virus on the other. Check plants used in the experiments remained healthy.

To parallel the work with sweet pea, attempts were being made from time to time to transmit a streak disease of garden pea (Pisum sativum) occasionally found in the field. In December, 1935, a number of plants showing streak symptoms were found in San Luis Obispo County in a winter planting of peas grown on the coast. The plants showed brown necrotic spots on the foliage, darkening of the veins, reddish-brown to purple streaks on the stems, and blighting of the tops. Pods showed circular spotting or, in advanced stages, a pitted necrosis. Death of the pods was marked by a purplish-bronze cast. These symptoms, since described by Whipple, ${ }^{(\theta)}$ are illustrated in figure $1, B, C$, and $E$.

With the juice from these plants, spotted wilt symptoms were obtained on Nicotiana glutinosa and N. tabacum, and in addition 2 out of 16 inoculated sweet-pea plants developed streak. Inoculation of the spotted wilt virus into Perfection peas from infected tomato yielded 4 infections out of a possible 13 ; from infected tobacco 5 out of 10 plants were infected; and from Romaine lettuce 10 out of 31 showed systemic infections, while 20 of the 31 showed local lesions. These and other similar data obtained from cross-inoculations with the pea streak and spotted wilt virus have confirmed Whipple's results and conclusions upon the identity of these viruses.

Transmission of the spotted wilt virus to sweet pea was also obtained by means of thrips. Infective larvae and adults of Thrips tabaci Lind., 
obtained from head lettuce infected with the spotted wilt virus, were caged on healthy sweet peas in the greenhouse. In the first series, 4 out of 34 plants became infected, typical symptoms of the disease appearing in 20 days. In the second series 3 out of 31 plants were infected, symptoms appearing in 30 days. At the same time the virus was successfully transmitted by thrips to garden pea in confirmation of Whipple's work.

\section{DISCUSSION}

Symptoms on sweet pea resembling a streak have been reported by Zaumeyer and Wade ${ }^{(7)}$ after inoculation with mosaic viruses from white sweet clover and white clover. The virus involved in both cases may be Pierce's ${ }^{(2)}$ white clover virus 1.

The streak disease of sweet pea reported here is now recognized as an important factor in sweet-pea culture in certain coastal districts of California, and probably occurs in other regions where the spotted wilt virus is present. Its seriousness may be felt especially where sweet peas are planted in the vicinity of spotted wilt host crops in these districts at seasons when large migrations of the thrips vector may take place. Because of the long list of common ornamentals known ${ }^{(1)}$ to harbor the virus, garden plots of sweet peas are particularly liable to infection, owing to the many likely sources of the virus at hand at all times of the year. In the writers' experience it is frequently impractical to grow sweet peas to a satisfactory conclusion in private gardens in infested districts. When infected early, the plants fail to grow as they should, turn yellow, and, if they do not die, are lacking in productiveness and quality.

Circumstances attending the disease may hinder immediate diagnosis. There may be only a partial display of the symptoms, and where streaking only is evident, it resembles a bacterial disease. Tissue plantings on agar media from necrotic stem lesions were sterile except for occasional colonies of bacteria in two lots of material cultured. These bacteria, when sprayed on healthy plants in a humidity chamber, produced no infection.

A common complication of the streak disease is caused by mixtures with mosaic viruses. Among other virus diseases Stubbs $^{{ }^{(4)}}$ enation mosaic of pea (pea virus 1) and Pierce's ${ }^{(2)}$ common pea mosaic (pea virus 3) are found on sweet pea in California. Where a mosaic and streak occur together the tendency has been to attribute the severity of the symptoms to a high virulence of the mosaic virus, or to a mixture of mosaic viruses. However, it has been possible to isolate both the spotted wilt virus and a mosaic virus from plants showing the combined symptoms, by means of differential hosts. Also, the pea aphid (Macrosiphum pisi Kalt), not be- 
ing a vector of the spotted wilt virus, may be used to isolate the mosaic virus where mosaic and spotted wilt are present in the same plant. In mechanical inoculations with expressed juice the mosaics are usually transmitted in a much higher percentage of cases than spotted wilt. As a result only the mosaic virus may be recovered when the juice from a plant containing both viruses is applied mechanically to a common host. Other streaks of pea, however, may be more readily transmitted by mechanical inoculation.

Control of streak would seem to lie in the isolation of sweet pea plantings from crops susceptible to spotted wilt and from infested districts, or in the protection of plants from migrations of infective thrips.

\section{ACKNOWLEDGMENTS}

The writers gratefully acknowledge the helpful suggestions of Professors R. E. Smith and Max W. Gardner, and also thank the latter for authentic plant cultures of the spotted wilt virus used in this work.

\section{LITERATURE CITED}

${ }^{1}$ Gardner, M. W., C. M. Tompkins, and O. C. Whipple.

1935. Spotted wilt of truck crops and ornamental plants. [Abstract.] Phytopathology 25:17.

2 Pierce, W. H.

1936. The identification of certain viruses affecting leguminous plants. Jour. Agr. Research 51:1017-39.

${ }^{3}$ Rawlins, T. E., and C. M. Tompkins.

1934. The use of carborundum as an abrasive in plant-virus inoculations. [Abstract.] Phytopathology 24:1147.

4 StubBs, M. W.

1936. Viroses of the garden pea, Pisum sativum L. [Abstract.] Phytopathology $26: 108-9$.

- Taubenhaus, J. J.

1914. The diseases of the sweet pea. Delaware Agr. Exp. Sta. Bul. 106:1-93.

${ }^{\circ}$ W HIPPLE, OTIS, C.

1936. Spotted wilt of garden pea. Phytopathology 26:918-20.

' ZAUMEYER, W. J., and B. L. WADE.

1933. Mosaic diseases affecting different legumes in relation to beans and peas. Phytopathology 23:562-64. 